\title{
The Role of Formal and Informal Structures In Shaping the Corporation's Relational Capital
}

Professor Lesław H. Haber The School of Banking and Management in Kraków
1. "Management with the Spirit": almost a Laudation

It is the essence of every management and control system to attain specific objectives and implement assumed tasks. It is not, however, especially relevant here whether the managerial decisions concern a mega-firm, a corporation, a small business, or a work team. What counts is the personnel involvement and outcomes. However, the ways to attain objectives may be diverse. One can apply "hardcore" methods, based on formalized work relationships in which the hierarchy, obedience, availability, effectiveness etc. are observed. The workers are usually treated as workforce or human resources in such systems. On the other hand, one can apply "soft" methods in management, with the application of the achievements of sociology and psychology, in which strong emphasis is put on the workers' motivation, hierarchical flexibility, and partnership in decision-making processes. In those systems, the worker most often appears in the role of the corporation's social capital.

Professor Janina Stankiewicz has been involved in detailed analysis of the relevant management methods, in their both 
conceptual and applicable dimensions, for 45 years. Her creative and research outcomes make her an unquestionable authority in the area of the dissemination of the most recent achievements in modern management, as the contributor to 15 regular national conferences and the editor of the international "Management" journal published in English.

The uniqueness of the works of our highly respected colleague consists not only in the promotion of modern management methods in her numerous monographs and published and read papers, but also in the presentation of her own viewpoint, taking into account both advantages and threats associated with new management paradigms.

The innovation of her research approach is associated with the proposal to humanize management by the implementation of "management with the spirit," the conception referring to the community of entrepreneurs, managers, and workers who are united by one common goal: their company's success on the competitive market through partnership, responsibility, and trust.

I feel personally honoured to be able to participate in the celebration of Professor Janina Stankiewicz's anniversary and I would like to refer in my presentation to the question of "management with the spirit," which undoubtedly includes the role of the relational capital in corporate management.

The related issues only recently appeared in the scope of interest of Polish scholars studying knowledge management and the role of the intellectual capital in the improvement of corporate management methods. As a principle, relational capital is treated in most cases in the terms of positive phenomena in the enhancement of corporate management methods, although I think that such a statement is too biased. I rather claim that relational capital can produce either positive or negative effects in corporate management. Those are especially visible when we analyse the background of relational capital, in the form of the company's formal and informal structures which have not always been taken into account in recent conceptions (Rogoziński 2006, p. 16).

\section{Relational Capital in the Management Systems: Origin}

The concept of 'relational capital' as an analytical term appeared in the Polish management conceptions in the first decade of the 21st century. Obviously, that has been a fairly new term, but nevertheless, it focuses considerable interest among both research workers and business practitioners. Wiesław Danielak's monograph entitled "Shaping Relational Capital in Small and Medium-Sized Businesses," published by the Wrocław Economic University Publishing 
House in 2012, is considered by me to be an especially important contribution to the field in question. The substantive value of that book is associated with holistically presented relational capital issues, in the context of the relevant current conceptions. The author's tips on the mechanism of building, shaping, and development of relational capital, as a factor which strengthens small and medium-sized businesses' competitive edge, are very interesting for businessmen.

The practical dimension of relational capital and its practical application is presented by the collective work edited by Kazimierz Rogoziński, entitled "Managing Relations in Services," published by the Difin Publishing House in 2006. The analysis of service organizations as the corporations which practice relational marketing and operate either on a competitive market or in a market environment is the lead theme of the book. It is important to recognize the company's position which is assumed by it within the network of connections with other service market participants, e.g. on the medical service market. The book suggests specific indications for shaping relational marketing in services.

I would also include among the group of the works on the subject the threevolume monograph by Monika Marcinkowska on the "Relational Capital in the Bank," published by the Eódź University Publishing House in 2013. The author presents in an interesting way practical activities of the bank intending to acquire broadly understood stakeholders. She carries out her analysis at three levels: shaping the relationships between the bank and its environment, the relationships between the bank and the key stakeholders, and the appraisal of the bank's relational capital, as a conclusion of the bank's previous activities.

Theoretical and practical aspects of relational capital are found in the book supervised by Marek Cisek, entitled "Relational Capital in Modern Economy," published by the Studio Emka Publishers in 2009. The workers of the Institute of Management and Marketing of the Faculty of Management of the Podlaska Academy are the authors of particular sections of that book. The work is composed of two parts: theoretical one, which demonstrates the diversity of attitudes and theories of relational capital defining and structuring, and practical one, describing those areas of corporate activities in which the whole range of relationships, including logistics, sales, procurement, and marketing, lead to a considerable improvement of effective management.

The books presented and recommended here describe completely and complementarily the relational capital issues from both conceptual side and their practical value for a business environment. I would like to mention that the choice of books is my subjective choice and it does not decrease either the class 
and importance of other publications or studies that have not been mentioned here.

In the light of the literature mentioned above, 'relational capital' has been subjected to many interpretations and it proves to have a considerable substantive and practical value as an analytical category because of the following:

- it belongs to the company's goodwill and it affects the company's market value,

- it is part of intellectual capital, next to human capital and structural capital,

- it can become an important element in the knowledge management system, owing to its relationships with scientific and research components,

- it indicates the degree of dependence occurring between the company and its direct and indirect environments (mega, macro, and micro environments),

- it is a form of social capital as it allows to shape network relationships with stakeholders,

- in the architecture and building of relationship networks, the conception applies the most recent IT solutions (Internet, computers, satellites, callcentres...) that facilitate regular contacts not only in real space but also in virtual global networks,

- it underlines the roles of such company's stakeholder groups as workers, customers, contractors, buyers, suppliers, competitors, local governments, local communities, advocates, and media,

- it determines the relationships, inter-dependence, associations, contacts, formal-official and informal-personal relationships between the personnel and the company's stakeholders,

- it can be either beneficial for all the stakeholders, or harmful when benefits are incurred by only one stakeholder group at the cost of the others, or by the majority holders of the relational associations existing within the company's environment.

Taking into account the occurrence of durable and prospective relationships with stakeholders in corporate management, one should intend to transform one's relational resources into the capital, which is an additional market value of the company. The ongoing relational transformation must involve e.g. the following: aim, long-term and regularity of relationships, mutual benefits, and responsibility, producing the increase of mutual trust.

When analysing the essence of relational capital in the practical aspect, we can conclude that the term already appeared in various earlier management conceptions. Of course, we do not mean here the term's face value associated with the current meaning of 'relational capital' but rather its practical descriptions determining the occurrence of inter-relationships, relationships, inter- 
dependence, contacts etc. between various worker groups within a corporation, as well as the relationships with the market environment, which includes the broadly understood company's stakeholders.

In the case of administrative management following Weber's model of bureaucracy, a strong stress is put on formalization of the relationships developed between hierarchic worker groups, emphasizing formality, without personality of relationships. In that conception, the relationships occurring between management, workers, and stakeholders result from the adopted procedures and those are mutually observed.

However, in the case of the humanistic management conception, which features human relationships among others, the role of personal bonds between the management and workers is stressed. Such relationships between the workers and the management, including the owners are based on partnership: "...each of Walton's co-workers had a standing invitation to contact him personally in connection with any problems occurring in the company. Whoever wrote to Walton received a personal answer and whoever travelled to Bentonville could make an appointment with "Mr. Sam," as many workers called him" (Gross 1999, p. 230). We should mention that it was Sam Walton who established the Wal-Mart supermarket network. He employed 400,000 workers and became number one on the Forbes List of Billionaires in 1985, with the property estimated at 2.8 billion dollars. In the conceptions under discussion, relational capital was shaped by the increase of workers' satisfaction which was a factor of employment safety.

However, in the conceptions associated with the role of organizational culture in corporate management, a mutual respect and the observation of conduct models resulting from the company's tradition is assumed to be the foundation of the corporation-stakeholder relationship: "...in the conditions of renewal, we cannot allow ourselves to fail to appreciate organizational culture (...) as people think that the culture is a collection of obvious values, discussed assumptions, and mutual expectations; the culture provides unwritten and often unrealized rules of conduct" (Stankiewicz, Moczulska 2010, p. 599). In that case, shaping relational capital in the company was associated with a long-term internalization of common values, norms, and rules of conduct, as well as generally approved behaviour by workers, managers, and stakeholders. Long-term company's operation, its tradition, recognizable and well-established brand name, stable customer segment, and gradual innovation on a competitive market were the catalysts of developing relational capital under that management system.

The human resources management conceptions pay attention to the significance and role of the workers as the company's special internal stakeholders. The

The Role of Formal and Informal Structures In Shaping the Corporation's Relational 
treatment of the company's workers in terms of social capital is the main premise of that management system. The worker may not be a cost component but he constitutes rather an intangible intellectual asset who can develop himself by being entrepreneurial, creative, and innovative. In that case, relational capital is associated with a network of bonds, inter-dependences, contacts, and relationships that occur between the main company's stakeholders (workers) and managers. That caused historical changes in the manner of worker treatment: from labour force to worker potential to social capital to intellectual capital.

Nominally, the reference to the 'relational capital' term occurs in the current conceptions promoting a process approach in corporate management. That management system is based on: adhocratic principles, multi-specialty, flexible forms of employment, compensation negotiations, and changing tasks that require workers to be entrepreneurial, innovative, and creative. The foundation of the company's success on a competitive market depends on durable and multiple relationships with such broadly understood stakeholders as: workers, customers, subcontractors, buyers, suppliers, competitors, local communities, local governments, media etc. who are defined in scholarly terminology as the company's 'relational capital'. That type of a management conception is presented e.g. by the theories of benchmarking, re-engineering, outsourcing, networking, or Customer Relationship Management (CRM) (Haber 2011, p. 202).

Benchmarking stresses mainly the attainment of the market leader's position by the company, based on the analysis of market competitors. In that case, the company's relational capital is developed by relating to and possible co-operation with one of the stakeholders, being the local market competitor.

Re-engineering emphasizes the role of the customers as significant stakeholders treated in terms of relational capital; they are distinguished in the following segments of customers: individual, group, key, mass and other types of customers. The aim of that management type is to attain versatile fulfilment of the customer's needs in respect of quality, price, time, and high customer service standards.

Outsourcing intends to reduce constantly the company's operating costs and acquire external stakeholders who are able to carry out the orders concerning specialized tasks, within specific terms. Building relational capital based on external experts assures a regular access to professionals by the company, in the event that problems appear in the corporate management systems.

Networking assumes shaping relational capital on the basis of information flow, resources, acquaintances, mutual support, and the possibilities created by a network of mutual personal and business contacts between stakeholders. Such relationships contribute to the strengthening of contacts through efficient 
co-operation, and consequently, to new acquaintances and business contacts between stakeholders and market players.

Customer Relationship Management (CRM) concentrates on the conception of managing customer relationships. The purpose here is to increase the company's goodwill by increasing long-term customer satisfaction and loyalty. Relational capital, in the form of the customer bank, is also associated with the individual approach, taking into account the following: customer life cycle, use of IT in contacts, observation of the customer's personal preferences etc. The use of the Internet in cross-selling and up-selling types of contacts is innovative in that system. It allows customers to register their problems, search the solution base, and select the best possible option to remedy their problems.

In conclusion, we can say that the term of 'relational capital' has arrived in Poland and entered the research and study circulation associated with management system improvement quite recently. In the related publications, scholars and practitioners indicate the ambiguity of that term, underlining, however, that the feature allows for various research inspirations relating to the syndromatic analysis of that concept. Such possibilities have been indicated in this paper as well.

To put it simply, relational capital means "a network of co-operation, common norms, and values, as well as the use of the resources and potentials of the parties involved. It concentrates on the relational resources created on the basis of the relations existing between the company and its stakeholders (Danielak 2012, p. 50). Referring to the origin of relational capital, it was indicated that the related actions and effects were obtained in the preceding management systems, e.g. administrative, humanizing, or cultural orientations, in the form of formalization of contacts, human relationships, common behaviour patterns, or uniform values that are beneficial for the market players. That is why when referring to the nominal term of 'relational capital', we can state that the resultant practical forms of activities were equally accomplished earlier under other terms and in various corporate management systems.

\section{Formal and Informal Mechanisms of Shaping Relational Capital}

Tom Spaulding presented graphically the mechanism of shaping relational capital, in the form of a five-storey building:

1. Most of the relationships start on the first floor. We meet and greet people there. That is usually associated with a transactional exchange, e.g. when we need to obtain something specific from another person.

The Role of Formal and Informal Structures In Shaping the Corporation's Relational 
2. The next level of relations is placed on the second floor. That is the place where we start to share more information. But it is still basic information. We share it either because of social obligations or when that is expected from our position, not because we want to reveal who we are.

3. In the third-floor relationships, people develop a level of emotional comfort which exceeds beyond facts and data. Instead of maintaining weather-health conservations, we start to share our opinions and feelings.

4. The fourth-floor relationships are marked by a deeper and more meaningful sense. We share common interests, objectives, convictions, and matters. We also learn to overcome conflicts and we react in the manner which demonstrates that we appreciate our relationship for itself.

5. In the fifth-floor relationships, what people appreciate the most is sensitivity, authenticity, trust, and loyalty. Those are the relationships based on mutual empathy: intuitional understanding of one's needs, even those which we do not necessarily express.

The capability of reaching out to others is not limited. Before we get to the penthouse, first we have to learn how to leave the first floor. All the relationships require hard work, patience, understanding, and - although it can be surprising - strategy and tactics for the friendships to flourish. But that should not be confused with manipulation. What is the key to the creation of a rich network of relationships is understanding of the profound and principal truth that motivation is important. If one just wants to use other people to accelerate one's career and increase profit, the relationships will not be durable and valuable. Such an attitude can be effective either for a short time or in special circumstances, but the foundation on which we are building our contacts will be unstable and, consequently, our relationship will collapse, probably when we need it the most (Spaulding 2012, pp. 59-65).

The necessity to grade relationships, with the increasing intensity of positive contacts and dependence, is the main premise here. We should mention that all the related actions must be taking place within specific organizational structures. In the example quoted above, there is a five-storey building depicting the management structure of a company in which the storey functions are fulfilled by formal and informal structures on which the company's operation depends on the market, regardless whether it is a small business or a global mega-corporation. The company's stakeholders are moving between those structures: workers, customers, buyers, subcontractors, suppliers, competitors, representatives of the local community and local government or media etc., all connected by networks of relationships. Those relationships are characterized 
by e.g. purpose, regularity, long-term, mutual benefits, responsibility, trust etc., which consequently lead to the development of relational capital. However, we need to emphasize that the influence of formal and informal structures on shaping the company's relational capital can be either positive or negative (Krupski 2008, pp. 152-153). That would depend on the purpose and role fulfilled by the specific structures in the company's organizational system.

Formal structures are represented by the company's operating model through legality, rationality, and effectiveness of tasks. That is associated with the legal personality, sharing of responsibilities among the working positions and the assigned competences, remuneration, and communication systems inside and outside of the company. The position occupied within the company's structure is an essential element of operations and relationships. Graphic organizational charts, showing the hierarchy of the organization members or internal stakeholders related to the scope of their authority to make decisions (Haber 2000, p. 23), represent the "map" which determines the workers' actions and relationships. Relational capital will develop in that respect through mutual dependence occurring on the background of a given position, scope of decisionmaking, access to the company's resources, or skills in using IT. The relationships with external stakeholders will be taking place on the basis of the assumed procedures determining the company's rights and obligations as an organization, as well as those of internal and external stakeholders. That is associated with the company's participation e.g. in bidding procedures, contracting, negotiation of terms, establishment of operating strategies, concluding strategic alliances, observation of customers' rights etc.

The increase of the company's relational capital will also be affected by the degree of the company's involvement in the "Social Responsibility of Business," participation in various activities for the benefit of the local community or a national cause, e.g. in the activities of the "Great Orchestra of Christmas Charity" etc. The mechanism of shaping of the formal relationships which influence the relational capital development is presented by the example below, based on and interview conducted by myself:

"I occupy a managerial position and sometimes I have to manage our facility. I frequently rely on the relationships which I have been developing for years. An example of that can be our facility insurance bought from a well-known insurer. The origin of our co-operation goes back to 2003 when we signed our first insurance agreement to cover our building. However, our relationships were expanding every year: the insurer sponsored our community sports competitions and later our Children's Day or Christmas events. Another

The Role of Formal and Informal Structures In Shaping the Corporation's Relational 
stage of co-operation consisted in the placement of the insurer's billboards on our building or our workers' t-shirts. We strengthened our relationships by exceptional treatment of the insurer's employees, offering them high discounts for using our services. When talking about relationships, we should mention the persons we contact. They are not our acquaintances or colleagues any more. We know them well, we call them to ask to resolve our problems, we look for contacts or contractors through them to handle our company's affairs. Briefly, our companies are loyal to each other and our relationships are very strong. In fact, we have several contractors and suppliers of that type. I cannot imagine how one can run a business without good relationships with one's suppliers and contractors. Such relationships also refer to customer care. We always reward those who use our services. I know several persons who started with teaching their child to swim in our facility and later they brought their families to us. After learning to swim, they started to use the swimming pool on a regular basis. And that is how my role is important: building relationships which will cause that our customers get accustomed to us. We can offer them additional service packages, e.g. discount sauna periods, discount family swimming-pool tickets, gift coupons for wives, or invitations to our aqua aerobic classes. We always expand our service packages, thus strengthening our relationships. We also announce competitions that continue for at least six months for the customers to visit our facility regularly, use service packages, and come back after the end of competitions because our customers are well acquainted with our facility. At the end of each competition, we grant an award to one person, and in fact we gain many regular and new customers at the same time. In addition, we also try to create nice family-like atmosphere in our facility" (Kw. 22. K., 40 years old).

This example indicates how we can use the company's formal structure to build relational capital through regular acquisition of such stakeholders as customers, contractors, suppliers, local community members etc., always acting in accordance with regulations and procedures. The means applied here include a system of such legal incentives as have been specified in the company's regulations, e.g. sponsoring, discounting, coupons, attractive service packages etc. That example indicates that when acting within our organization or the formal structure of our management system, we can legally stimulate our company's relational capital development in a positive sense.

The informal structures developing as a result of the network of personal relationships existing in the hierarchy of workers and stakeholders often present a basis for shaping the company's relational capital. The specific relationships, bonds, and associations between particular workers and stakeholders are not 
determined by any company's statutes, rules or procedures. Our promoted patterns of conduct can be treated as sets of unwritten customary social principles. Informal structures are represented by spontaneous informal groups composed of our company's stakeholders: workers, customers, suppliers, subcontractors, contractors, representatives of local governments and communities or media.

The existence of informal groups depends on the degree of flexibility, rationality, and effectiveness of our formal structure. Informal groups can origin from formalism, underformalism, or overformalism of our management system. Formalism causes the development of informal groups, owing to low flexibility of our management system, which makes it difficult to react quickly to the changing company's environment. Underformalism creates procedural or legal gaps that prevent the development of informal relationships which use ambiguities for the attainment of one's own interests at the cost of the company's personnel or even at the cost of our community. Overformalism is associated with excessively detailed and rigorous regulations which cannot be handled by our personnel, and that can cause chaos and disorganization of our management systems.

Our knowledge of aims and relationships which connect the members of informal groups allows us to judge them as either being positive or negative. Positive determination concerns those informal structures or groups whose activities support the attainment of the objectives designed by our formal structures. Negative determination refers to those groups who use the irregularities occurring in the operation of formal structures to attain own selfish interests at the cost of the remaining stakeholders or the society at large (Haber 2000, p. 24). A positive phenomenon in the role played by informal structures (acquaintances, deals, or contacts) in shaping relational capital will be assigned to the dominating organizational culture and shaping work relationships, based on the principles of human resource management.

A positive example of shaping relational capital, based on informal mechanisms, is demonstrated by the description below which is part of an interview conducted with the workers and the owner of a hotel employing 30 people.

"The hotel owner admits that, owing to acquaintances, he was able to bring a derelict palace to its present condition. His acquaintances helped him even at the stage of the purchase of the palace. The present owner found a sale offer in the Internet. The price asked by the real estate agent was surprisingly low. Then, Mr. Wacław Nogaś, a friend of Jan, requested the municipality to verify the offer. The price turned out to be higher. Considerable resources were also required to repair the devastated landmark. Then, other acquaintances helped.

The Role of Formal and Informal Structures In Shaping the Corporation's Relational 
The Bielsko Region Landmark Conservator who was responsible for the area was their friend.

"Our "friendly" companies are extremely precious customers. They carry out about a dozen of training conferences a year, which assures our hotel maintenance. It is essential to keep positive relationships with such customers who actually should not be treated as customers, but even better than you treat your family members. Relationships with such customers are based on regular telephone contacts and analysis of the customers' needs. Each worker of our marketing department has an account list and he or she keeps in touch with our customers. Besides regular calls, with season greetings and invitations to the events taking place at the Palace Hotel, our customers can expect special prices. It is also important to know our customers' preferences. That will be necessary to arrange for all details relating to our customers' events, as well as assure efficient delivery of services. In the case of such friendly companies, small gifts are always in place. Mostly local and unique products are suitable.

"In addition to our guests acquired in such ways, the owner's acquaintances, or the acquaintances of his acquaintances, constitute a large customer group. The Wawel Castle Bell Brotherhood has its premises in the hotel. They organize regular meetings and annual admissions of new members, as well as special events, e.g. the Christmas Eve dinners. The owner's acquaintances also run their businesses and the Paszkówka Palace Hotel is their main conference centre, providing conference rooms and facilities. Information is spread by word of mouth: "You know, my friend has a hotel; give him a call and mention my name; you'll get a good price."

"Besides, the hotel employees create a specific group. They constitute an exceptionally harmonious team. They jointly experience the joy of successes and the bitterness of failures here. The hotel management system developed by the owner assumes support extended by each worker. The workers have to respect and like each other. Any tensions are resolved very quickly. Our hotel guests are excellent observers. We can judge by their behaviour during their stay whether the service team is well coordinated and the members understand each other. What is very important in team relationships is that each manager must have worked on all the positions that he currently manages. That gives him or her an excellent knowledge of the work at each position, and the workers are not forced to do what is not realistic" (Kw. 15, M., 50 years old).

Although we are dealing with a company as a legal entity, which is a typical formal organization, we can identify the significance of informal structures at each stage of the company's operation, together with consequential associations 
in the form of acquaintances, referrals, communications etc. Those ties assisted the owner in the business acquisition, development, and expansion. The processes were carried out through friendly companies (strangers refused to cooperate), acquaintances, finding new collaborators, word of mouth, additional gifts and bonuses, and personal relationships between the staff and the owner, as well the workers who were interested in the provision of the highest possible quality of service to their customers.

Comparing those two examples, illustrating the role of formal and informal structures in shaping the company's relational capital, we can notice a considerable similarity of the shaping mechanisms:

1. In both cases, the company's organizational structures determined the future architecture of relationships; in one case, based on procedures, and in the other one, based on personal connections.

2. In both cases, the relationship space was not a clear-cut formal or informal structure. Both structures permeated each other to build a combined system in which one structure could dominate in the relational capital creation: either the formal or the informal one, that is either the procedural or personal relationship.

3. In both cases, the relationship resources were shaped in accordance with Tom Spaulding's five-storey building model: Storey I: identification of stakeholders, Storey II: initial contacts, Storey III: strengthening of contacts, Storey IV: appreciation of contact importance and durability, Storey V: mutual benefits and continuation of contacts by the stakeholders.

4. In both cases, the developed relational capital constituted the foundation of the company's development in the substantive dimension - based on economic indicators - moral aspects, and the company's prestige in its environment, as well as durable relationships with the company's internal and external stakeholders.

5. In both cases, the relational annuity consists in the stakeholders' loyalty and readiness for further co-operation, as well as reliable and prospective position of the company on the competitive market.

\section{The Influence of Formal and Informal Structures on the Relational Capital Appraisal}

The previously quoted examples of the companies indicated the positive influence of formal and informal structures on shaping the company's relational capital. Nevertheless, such structures can also have a negative impact on the

The Role of Formal and Informal Structures In Shaping the Corporation's Relational 
nature of relational capital in the company's organizational space. PBS DGA conducted surveys to examine the range of negative evaluations concerning the use of relational capital by businesses. The survey results indicated that, in the opinion of $41 \%$ of the respondents, businesses applied various informal activities, including some aspects of relational capital, to attain business gains. The success of one's own company was owed to personal acquaintances, business associations, deals with the authorities over lucrative public orders, or contracts offered by non-government organizations (Piechowiak 2013, bankier.pl).

Those evaluations were confirmed by my own interviews with 30 entrepreneurs from Kraków during a social meeting in November 2013. The interviewed businessmen were the owners of their companies operating in various fields: manufacturing, services, trade, recreation etc., aged 27-35, employing people for 3-5 years. I could describe them as a group of young businessmen, well established on the market, owing to the constant development of their organizations.

When asked whether acquaintances, deals, or favouritism helped them in running their businesses, $65 \%$ confirmed that they fully used their acquaintances, $20 \%$ declared that they hardly used them, and $15 \%$ took completely independent steps to establish and run their own companies. According to $75 \%$ of the respondents, assistance was associated with various reciprocal obligations towards the respective persons. Most often, mutual financial obligations or services were involved. Such acquaintances, according to $80 \%$ of the businessmen, have been continued until today and the respondents can rely on regular help in case of any difficulties they face in their business activities. Most often, help concerned the following:

- $70 \%$ : various administrative matters connected with running a business,

- 50\%: keeping the company's documentation,

- $48 \%$ : acquisition of customers, buyers, or contractors,

- 45\%: facilitation of contacts with businesses, local governments and communities, and media,

- 30\%: helping in winning bidding procedures,

- $28 \%$ : handling matters at the taxation office,

- 25\%: facilitation of contacts with public administration,

- 18\%: generation of income in the "grey zone".

There was no businessman who declared that he never used any form of help provided by acquaintances. Nearly $90 \%$ of them stated that their businesses would go bankrupt without their "guardians."

My survey results indicate that the relational capital development is indispensable for the market activities of small and medium-sized businesses. 
We should emphasize that the very fact of maintaining acquaintances is not negative because quite often such acquaintances are the foundations of relational capital. Nevertheless, the method of use of one's acquaintances can be either positive: increased group of the stakeholders interested in developing one's business, or a negative: favouritism, nepotism, corruption, or organized crime, often of the mafia nature.

It is, however, controversial, in both negative and positive senses, when jobs or promotions are arranged for acquaintances, based on informal relational networks or the position of a given person in the system. In other words, one may or may not be recommended to be employed or promoted. It is true that for the majority of people in Western Europe, e.g. France, UK, Germany, Austria, Italy etc., getting a job or promotion is frequently dependent on the type of school, social origin, family connections, or informal contacts, and only later on personal skills and work outcomes (Mole 2000, pp. 37, 58, 85, 104, 125, and 144). A similar situation starts to develop in Poland where references, recommendations, or informal acquaintances can be decisive about admission or promotion. We should, however, mention that such cases occur mostly in public administration agencies and state-owned enterprises rather than private businesses, where informal relationships can be decisive for hiring, although promotion would rather be based on work outcomes and especially on the worker's commitment to the company's development.

What is extremely wrong in shaping relational capital is the "overlap" of informal and formal structures, where either personal gains or group interests are attained at the cost of the company's personnel or the local community. In such situations, a formal structure is a cover for criminal activities, based on informal relational networks for personal gains at the cost of the remaining stakeholders.

When starting to appraise the conduct related to formal and informal relational capital aspects, I would like to mention the capital's diverse role in the corporate organizational structure. Here, we can identify other research areas where relational capital not only raises the company's competitive edge, but it can also present a threat to the company's development.

\section{Relational Capital Is the "Spirit" of Management: Final Comments}

When presenting the interdependence between relational capital and its formal and informal background, I was trying to identify the mechanism of its origin, development, and appraisal. considering the fact that the term is a fairly

The Role of Formal and Informal Structures In Shaping the Corporation's Relational 
new analytical terms in the management science. The term has already raised considerable interest on the part of theoretical and practical analysts working on the improvement of management methods and business practices. We should further mention that a number of actions resulting from the application of this term occurred earlier in the humanistic management approach: human relations, organizational culture, or human resources management, where main actions were focused on the acquisition of the worker as a joint creator of the company's success. What is new, however, is the application of relational capital in the corporate management process systems, where it is required to react quickly to the needs identified in the environment and deepen formal and informal relationships with broadly understood company's stakeholders.

Treating relational capital as the "spirit" of present-day management, we should emphasize that relational capital concerns the social behaviour of all the market players, the company's all stakeholders. People point out the stakeholders' motivations, emotions, and relationships which are released at the important moments of corporate management. Those can either facilitate or harm the company's development. Thus, based on the "spirituality" of relational capital, we can conclude that relational capital is included in the company's goodwill and it constitutes part of intellectual capital, together with structural human capital. We need to emphasize that the practical application of relational capital brings measurable financial profits to the companies, such as those specified by W. Danielak (2012, p. 184):

- in reference to workers: increase of work effectiveness, increase of the number of workers improving their qualifications, reduced implementation time for new projects, better worker availability etc.,

- in reference to customers: increase of the number of customers, increase of sales, increase of sales to existing customers, increase of satisfaction, increase of the frequency of contacts etc.,

- in reference to suppliers: continuity, certainty, and high quality of supplies; suggesting market innovations, extended terms of payment etc.,

- in reference to competitors: market co-operation, starting strategic alliances, offering assistance in case of threat etc..

I would supplement that list with the subcontractors who wish to continue long-term co-operation; the local community members who approve of the company's activities, become the company's customers, and contribute to the company's market stability; the representatives of local authorities who can recommend the company for participation in various projects of business, cultural or recreational nature etc., making the company and its brand popular;

LESŁAW H. HABER 
or a positive image of the company in local press, radio, and TV. The Internet can become a free and inexpensive marketing tool to promote the company even in large communities. Based on networking, relational capital allows us to start and strengthen business contacts, assuring continuous substantive development of the company. Therefore, we can conclude that relational capital is the company's intangible asset; positive effects of its application have specific material dimension and they clearly influence the company's market value.

In conclusion, I would like to mention that the "spirit" of relational capital may not only positively affect our management system, but it can also generate some pathological symptoms. Such phenomena may occur when the relational capital shaping activities are influenced by informal structures and such consequential relational obligations as cronyism, clientism, nepotism, favouritism or corruption when actions are designed for selected stakeholders whose purpose is to attain personal gains. But still, I think that further works on the role of relational capital will concentrate rather on the positive nature of the "spirit", taking into account that improved governmental and institutional inspection agencies will supervise adequately corporate business operations.

\section{Abstract}

The Role of Formal and Informal Structures In Shaping the Corporation's Relational Capital

The paper presents the origin of the term of 'relational capital' by reference to such previous management systems as human relations, organizational culture, or human resources management. At the same time, the author indicates the significance of relational capital in the recent conceptions associated with the treatment of management as a process. On that background, the roles of formal and informal structures in shaping relational capital are discussed, marking both positive and negative influence of such capital in the corporate management system.

Key Words: relational capital, management systems, formal structures, informal structures, positive and negative aspects of relational capital.

\section{Streszczenie}

Rola struktur formalnych i nieformalnych $w$ kształtowaniu kapitału relacyjnego przedsiębiorstwa.

W artykule przedstawiono genezę kapitału relacyjnego odwołując

The Role of Formal and Informal Structures In Shaping the Corporation's Relational 
się do wcześniejszych systemów zarządzania jak human relations, kultura organizacyjna, czy zarządzanie zasobami ludzkimi. Jednocześnie wskazano na znaczenie kapitału relacyjnego $\mathrm{w}$ nowszych koncepcjach związanych z procesowym traktowaniem zarządzania. Na tym tle omówiono role struktur formalnych i nieformalnych $\mathrm{w}$ kształtowaniu się kapitału relacyjnego zaznaczając jego pozytywny ale i negatywny wpływ na system zarządzania przedsiębiorstwem.

\section{Słowa}

kluczowe: kapitat relacyjny, systemy zarzadzania, struktury formalne, struktury nieformalne, aspekty pozytywne i negatywne kapitatu relacyjnego.

\section{References}

1. Cisek M. (Ed.) (2009), Kapitat relacyjny w nowoczesnej gospodarce, Wyd. Studio Emka, Warszawa.

2. Danielak W. (2012), Kształtowanie kapitału relacyjnego w matym i średnim przedsiębiorstwie, Wyd. Uniwersytetu Ekonomicznego we Wrocławiu.

3. Gross D. (Ed.) (1999), Forbes o największych sukcesach w świecie biznesu, Wyd. Naukowo-Techniczne, Warszawa.

4. Haber L.H. (2000), Organizacja formalna i nieformalna, In: Encyklopedia Socjologii, Vol. 3, Oficyna Naukowa, Warszawa.

5. Haber L.H. (2011), Komunikowanie i zarządzanie w społeczeństwie informacyjnym, Nomos, Kraków.

6. Krupski R. (Ed.) (2008), Elastyczność organizacji, Wyd. Uniwersytetu Ekonomicznego we Wrocławiu, Wrocław.

7. Marcinkowska M. (2013), Kapitat relacyjny banku, Vols. I, II, III, Wyd. Uniwersytet Łódzki, Łódź.

8. Mole J. (2000), W tyglu Europy. Wzorce i bariery kulturowe w przedsiębiorstwach, Wyd. Prószyński i S-ka, Warszawa.

9. Piechowiak Ł. (2013), Bez znajomości i układów nie zrobisz biznesu, In: bankier.pl (Access: 10.12.13.

10. Rogoziński K. (Ed.) (2006), Zarzadzanie relacjami w ustugach, Difin, Warszawa.

11. Spaulding T. (2012), Nie chodzi tylko o to, kogo znasz, Wyd. MT Biznes, Warszawa.

12. Stankiewicz J., Moczulska M. (2010), Wartości - istotny element kultury organizacyjnej w warunkach odnowy (w świetle wyników badań), In: J. Skalik (Ed.), Zmiana warunkiem sukcesu. Odnowa przedsiębiorstw - czego nauczył nas kryzys, Wyd. Uniwersytetu Ekonomicznego we Wrocławiu. 